\section{Health care seeking due to COVID-19 related symptoms and health care cancellations among older Brazilian adults: the ELSI-COVID-19 initiative}

\author{
Procura por atendimento médico devido \\ a sintomas relacionados à COVID-19 e \\ cancelamento de consultas médicas em função \\ da epidemia entre adultos brasileiros mais \\ velhos: iniciativa ELSI-COVID-19
}

\author{
Búsqueda de atención sanitaria debido a la \\ COVID-19, síntomas relacionados y denegaciones \\ de asistencia sanitaria entre brasileños mayores: \\ la iniciativa ELSI-COVID-19
}

James Macinko 1

Natalia Oliveira Woolley 1

Brayan V. Seixas 1

Fabiola Bof de Andrade 2

Maria Fernanda Lima-Costa 2,3

doi: 10.1590/0102-311X00181920

\begin{abstract}
The continent of the Americas has the greatest number of people infected and deaths associated with severe acute respiratory syndrome coronavirus 2 (SARS-CoV-2) in the world. Brazil occupies the 2nd position in numbers of infected cases and deaths, preceded only by the United States. Older adults and those with pre-existing chronic illnesses are more vulnerable to the consequences of the virus. The SARS-CoV-2 epidemic has serious consequences for health services. Therefore, an assessment of the pandemic's effect on the older Brazilian population is urgently needed. The study examines the prevalence of COVID-19 related symptoms, care-seeking, and cancellation of surgery or other scheduled medical care among a nationally representative sample of Brazilians aged 50 and over derived from the Brazilian Longitudinal Study of Aging (ELSI-Brazil) and a telephone follow-up survey (the ELSI-COVID-19 initiative) between late May and early June 2020. About $10.4 \%$ of older adults reported any fever, dry cough or difficulty breathing in the 30 days prior to the interview, with the highest prevalence in the North region (50\%). Among individuals with symptoms, only 33.6\% sought care. Individuals living in the South or Southeast regions were significantly less likely to seek care for COVID-19 related symptoms. Nearly one in six participants had to cancel scheduled surgery or other medical care; this proportion was higher among women, those with more education, and people with multiple chronic conditions. This paper is among the first to investigate the effect of COVID-19 on health care use in Brazil among older adults. Results highlight the need to adapt health care delivery (such as through telemedicine) to ensure the continuity of care as well as the urgent need for wide dissemination of information to guide the population on disease prevention measures and how to obtain healthcare when needed.
\end{abstract}

\author{
Correspondence \\ J. Macinko \\ Fielding School of Public Health, University of California. \\ $35 \mathrm{~W}$ 4th Street, 12th Floor, Los Angeles, California 90095, \\ U.S.A. \\ jmacinko@ucla.edu \\ 1 University of California, Los Angeles, U.S.A. \\ 2 Instituto René Rachou, Fundação Oswaldo Cruz, \\ Belo Horizonte, Brasil. \\ 3 Programa de Pós-graduação em Saúde Púbica \\ Universidade Federal de Minas Gerais, Belo Horizonte, Brasil.
}




\section{Introduction}

The COVID-19 pandemic, caused by the severe acute respiratory syndrome coronavirus 2 (SARS-CoV-2), has quickly spread worldwide. As of June 16th, 2020, about 8 million people had been infected and 434,796 have died 1. The first case of COVID-19 in Brazil was diagnosed in late February 2020, and by mid-June, the country had registered near 1 million infections and 45,241 deaths, placing Brazil as the second most affected country, after the United States (Coronavírus Brasil. Painel coronavírus. https://covid.saude.gov.br/, accessed on 21/Jun/2020).

The COVID-19 mortality rate in Brazil is about 22.8 per 100,000 inhabitants, the world's sixth highest (Johns Hopkins Coronavirus Resource Center. Mortality analyses. https://coronavirus.jhu. edu/data/mortality, accessed on 21/Jun/2020). Such as in other countries affected by the pandemic 2 , Brazilians older than 50 years (as of June 9 2020, 86\% of COVID-19-related deaths in Brazil were in this age group) and those with underlying health conditions are at higher risk of death (Ministério da Saúde. Boletim Epidemiológico Especial. https://coronavirus.saude.gov.br/boletins-epidemiologicos, accessed on 21/Jun/2020).

Brazil's five geographic macro-regions (i.e. North, Northeast, Central, Southeast, and South) differ on most social, economic, and epidemiological measures 3 . Regional differences are similarly pronounced for COVID-19 infection rates. São Paulo, the most populous state of the country, has had the largest number of infections, at about one out of every five reported cases (Coronavírus Brasil. Painel coronavírus. https://covid.saude.gov.br/, accessed on 21/Jun/2020). However, per capita infection and mortality rates have been higher in the North and the Northeast regions (Coronavírus Brasil. Painel coronavírus. https://covid.saude.gov.br/, acessado em 21/Jun/2020) with states such as Amapá and Amazonas reporting, respectively, 1 in 46 and 1 in 70 people infected 4 .

In Brazil, sufficient measures of physical distancing, testing, and contact tracing have not been put in place to curb the spread of infection 5,6. Moreover, closures of schools, office buildings, and shopping malls 5 have been unevenly adopted across the country 7 , and adherence levels have fluctuated 8,9 . As a result, the rapid rise in COVID-19 infections has severely affected the Brazilian health system, especially in states with more fragile health care infrastructure. In the Northern and Northeastern regions capitals such as Rio Branco (Acre State), Natal (Rio Grande do Norte State), Belém (Pará State) and Fortaleza (Ceará State), more than $90 \%$ of hospital intensive care units (ICU) were occupied by mid-May 10 .

The SARS-CoV-2 epidemic has serious consequences for health services, with hospitalizations representing just the tip of the iceberg. Other consequences have received little attention and are the subject of this study. Our objective was to examine the prevalence of symptoms of COVID-19, healthcare seeking due to these symptoms, and the cancellation of surgeries or other previously scheduled procedures due to the pandemic. The study included 6,149 adults aged 50 years and older, participants in the Brazilian Longitudinal Study of Aging (ELSI-Brazil), who responded to a telephone interview about COVID-19 between the end of May and the beginning of June 2020.

\section{Methods}

ELSI-Brazil is a longitudinal, household survey conducted in a national sample representative of the Brazilian population aged 50 years and over. Participants were drawn from a multi-stage cluster sample, stratified by municipality, census tract, and residence. The baseline assessment occurred in 2015-2016 with subsequent data collection scheduled to occur every 3 to 4 years. A total of 9,412 people, across 70 municipalities and all five major geographic regions were part of the first wave of the study, which included: (1) household interviews; (2) individual interviews; (3) physical measurements; and (4) blood tests. A more detailed methodological description can be found elsewhere 11.

The second wave of data collection started in August 2019 but was put on hold on March 17th, 2020 (after completing 9,177 of a planned 9,412 total interviews) due to the COVID-19 outbreak in Brazil. A five-minute telephone interview was created to assess the effect of the pandemic on ELSI-Brazil participants. The first round of telephone interviews was carried out between May 26th and June 8th, 2020. Two subsequent rounds are scheduled to occur, at each 60 days apart. All 9,177 people who had so far been interviewed in the second wave were eligible for telephone interview. Telephone 
survey questions addressed social distancing practices, use of face mask, handwashing, food and medication assistance, COVID-19 testing, and health service use, among other topics.

Trained interviewers carried out the telephone assessments using an electronic template for data entry, enabled with real time data transmission of results. Letters and text messages were sent out to eligible participants prior to the telephone calls to increase the number of participants. People who declined to participate during the first call (about $4 \%$ of non-responses), did not answer any of the five subsequent calls (about $33 \%$ of non-responses), or did not have an accurate phone number (58\%) were treated as "refusals." Considering this, the final response rate for telephone interview was $67 \%$. To compensate for non-responses, specific weights were derived for those who answered the telephone interview that consider their age, sex and education level. Based on these weights and other sample parameters, participants in the telephone survey were similar to the Brazilian population aged 50 or over in relation to average age, sex, level of education, region of residence, type of residence (in rural or urban areas) and race/color. For a more thorough description of the telephone survey protocol and other characteristics of participants, see Lima-Costa et al. 12.

\section{Measures}

The main outcomes derived from the ELSI-COVID-19 telephone survey are: (1) reporting any one of the three main COVID-19 symptoms in the past 30 days, including fever, persistent dry cough, and/ or difficulty breathing; (2) any report of seeking health services as a result of any of the previously listed symptoms; and (3) reporting whether any previously-scheduled surgery or medical care had to be canceled due to the COVID-19 pandemic.

The main descriptive variable is region (North, Northeast, South, Southeast, Central), considering the differences among regions in economic development, health conditions, and health service availability.

In order to present comparable, descriptive results, we include variables related to higher risk of COVID-19 from the ELSI-Brazil wave two dataset: age, sex, and the presence of any previously diagnosed chronic conditions (asthma, arthritis, cancer, depression, diabetes, heart diseases, hypertension, kidney disease, Parkinson's, and Alzheimer's). We tested other potential risk factors (smoking status and household income), but they were not significantly associated with any outcome and did not improve overall model fit, so they were not included in final statistical models.

We also assess factors that may contribute to the need for and availability of health services-independent of COVID-19 symptoms or concerns - including educational level, marital status (partnered versus others), and type of health care coverage. All these data were derived from the ELSI-Brazil cohort data. Health care coverage is defined by those who have a private health plan, those whose household was registered with the Family Health Strategy (FHS), and those who neither have private health plan nor FHS coverage but are nevertheless covered by the traditional public health centers (referred to as UBS).

\section{Statistical analysis}

We present descriptive statistics as weighted proportions and, asr we use complex survey data, statistical significance is obtained through an adjusted Wald test 13. Estimates of adjusted prevalence rate ratios are made using robust Poisson regression since some outcomes have rates over 10\%. All statistical models were built in a forward stepwise fashion, retaining variables found to be statistically significantly associated with the outcome and/or that improved model fit. We estimate predicted probabilities from the final, fully adjusted models to illustrate regional differences for selected outcomes. Sensitivity analyses were also performed to investigate factors that could potentially explain or confound observed results. All analyses control for the survey's sample design and include final sample weights.

Both the ELSI-Brazil study and ELSI-COVID-19 initiative were approved by the Research Ethics Committee of the Fundação Oswaldo Cruz, Minas Gerais (CAAE: 34649814.3.0000.5091 and CAAE: 33492820.3.0000.5091, respectively). 


\section{Results}

Descriptive statistics for several variables stratified by region are shown in Table 1 . We found substantial geographic variation in the prevalence of self-reported COVID-19 symptoms. Whereas in the Central region only $4.9 \%$ (95\% confidence interval - 95\%CI: 3.3\%-7.5\%) of the population over 50 years reported having had fever, dry cough or difficulty breathing in the past 30 days, that number was 46\% (95\%CI: 29.8\%-63.0\%) in the North region. Among those who reported any COVID-19 related symptom, the proportion of people that sought care also significantly varies across geographical regions. In the South, approximately $11.4 \%$ (95\%CI: $5.8 \%-21.0 \%)$ sought care in contrast with $56.1 \%$ (95\%CI: 24.3\%-83.6\%), 36.1\% (95\%CI: 23.7\%-50.6\%), and 21.7\% (95\%CI: 13.7\%-32.6\%) in the North, Northeast, and Southeast, respectively. Previous doctor visits (pre-COVID-19) also varied by region. The highest prevalence was in the North with 90.7\% (95\%CI: 77.4\%-96.6\%), followed by the Southeast at $82.6 \%$ (95\%CI: $75.2 \%-88.1 \%)$. The lowest prevalence was noted in the South at $70.3 \%$ (95\%CI: $58.4 \%-79.9 \%)$. Neither the prevalence of chronic conditions nor health care coverage was statistically different across geographic regions.

Table 2 presents adjusted prevalence ratios obtained from multivariate robust Poisson regression for three outcomes: (1) any self-reported COVID-19 related symptom; (2) whether the participant sought care for any COVID-19 symptoms; and (3) cancellation of previously-scheduled surgery or other medical care due to the COVID-19. Participants that presented multiple chronic conditions were positively associated with having reported any COVID-19 related symptom in the 30 days prior to the interview. Those with three or more chronic conditions have a prevalence for this outcome that is, on average, 3.16 times higher than the estimated prevalence for those without any chronic conditions, all else equal. Participants that live in the North region were positively associated with having reported any COVID-19 related symptom. Generally, residing in other regions was associated with a reduction of at least $76 \%$ in the prevalence ratio for this outcome, after controlling for all other variables in the model.

Living in the South region is associated with a reduction of $71 \%$ in the adjusted prevalence rate for having sought care in comparison to the North region, while living in the Southeast is associated with a $47 \%$ reduction.

We estimated the predicted probabilities of seeking care for COVID-19 symptoms by region and age group based on the final regression model. As Figure 1 presents, the South, Southeast, and Central regions have lower point estimates, around 10-20\% for adults between 50 and 80 years old in comparison to estimates over $40 \%$ in the North region. Note that, several differences among the bars of Figure 1 are not statistically significant at the conventional level of $\mathrm{p}<0.05$.

Regarding the cancellation of scheduled care, women are more likely than men to have care canceled (the prevalence among women is $47 \%$ higher than that of men, all else equal). Educational level is positively associated with this outcome. In comparison to individuals with less than five years of schooling, those who have nine or more years of schooling present, on average, $77 \%$ higher prevalence, after adjusting for covariates. Similarly, chronic diseases are associated with cancellations of scheduled care due to COVID-19. As shown in Table 2, the magnitude of this association increases with the number of chronic conditions. Having had a doctor visit in the year prior to the beginning of the pandemic is also associated with a higher likelihood in canceled care due to COVID-19. On average, individuals who had a previous doctor visit are expected to present a prevalence for having canceled scheduled care more than twice as large as those who had not previously visited a health care provider. Lastly, those living in the Southeast region have an adjusted rate of having canceled scheduled care twice as large as that of individuals living in the North.

Figure 2 presents predicted probabilities for scheduled care cancellations, which are stratified by sex, chronic conditions, and geographic region. Firstly, it is important to highlight the gradient effect of chronic conditions, i.e., the greater the number of conditions, the higher the predicted probability of presenting a cancellation of scheduled care. Secondly, there are significant variations across regions. Individuals in the Southeast stand out for presenting a higher predicted probability associated with scheduled care cancellation compared to those living in other Brazilian regions. Lastly, there are notable differences between men and women, with women presenting higher predicted probabilities associated with scheduled care cancellation across regions and number of chronic conditions. 
Characteristics of participants aged 50 or older of the ELSI COVID-19 telephone interview, by region *

\begin{tabular}{|c|c|c|c|c|c|c|c|}
\hline \multicolumn{8}{|c|}{ Weighted proportions $(95 \% \mathrm{Cl})$} \\
\hline & $\begin{array}{c}\text { North } \\
{[n=306]}\end{array}$ & $\begin{array}{l}\text { Northeast } \\
{[n=1,745]}\end{array}$ & $\begin{array}{l}\text { Southeast } \\
{[n=2,510]}\end{array}$ & $\begin{array}{l}\text { South } \\
{[n=831]}\end{array}$ & $\begin{array}{l}\text { Central } \\
{[n=717]}\end{array}$ & $\begin{array}{c}\text { Total } \\
{[n=6,149]}\end{array}$ & P-value ** \\
\hline $\begin{array}{l}\text { Any COVID-19 related } \\
\text { symptoms } * \star *\end{array}$ & $\begin{array}{c}45.96 \\
(29.79-63.02)\end{array}$ & $\begin{array}{c}10.6 \\
(8.05-13.82)\end{array}$ & $\begin{array}{c}6.93 \\
(5.04-9.45)\end{array}$ & $\begin{array}{c}8.47 \\
(4.74-14.70)\end{array}$ & $\begin{array}{c}4.95 \\
(3.26-7.46)\end{array}$ & $\begin{array}{c}10.44 \\
(6.96-15.39)\end{array}$ & 0.0000 \\
\hline $\begin{array}{l}\text { Sought care for } \\
\text { symptoms }\end{array}$ & $\begin{array}{c}56.14 \\
(24.28-83.63)\end{array}$ & $\begin{array}{c}36.05 \\
(23.69-50.58)\end{array}$ & $\begin{array}{c}21.69 \\
(13.70-32.58)\end{array}$ & $\begin{array}{c}11.35 \\
(5.82-20.97)\end{array}$ & $\begin{array}{c}14.19 \\
(4.56-36.40)\end{array}$ & $\begin{array}{c}33.58 \\
(16.65-56.12)\end{array}$ & 0.0300 \\
\hline $\begin{array}{l}\text { Scheduled health care } \\
\text { was canceled }\end{array}$ & $\begin{array}{c}12.27 \\
(6.40-22.23)\end{array}$ & $\begin{array}{c}15.19 \\
(10.19-22.03)\end{array}$ & $\begin{array}{c}23.73 \\
(18.74,29.56)\end{array}$ & $\begin{array}{c}11.91 \\
(8.57-16.31)\end{array}$ & $\begin{array}{c}7.22 \\
(6.06-8.57)\end{array}$ & $\begin{array}{c}17.18 \\
(14.19-20.65)\end{array}$ & 0.0002 \\
\hline Age (mean) & $\begin{array}{c}61.14 \\
(59.31-62.98)\end{array}$ & $\begin{array}{c}62.99(61.59- \\
64.40)\end{array}$ & $\begin{array}{c}63.77 \\
(61.97-65.57)\end{array}$ & $\begin{array}{c}63.71 \\
(62.26,65.16)\end{array}$ & $\begin{array}{c}63.49 \\
(60.97,66.01)\end{array}$ & $\begin{array}{c}63.35 \\
(62.43-64.27)\end{array}$ & 0.2149 \\
\hline Female & $\begin{array}{c}59.25 \\
(41.35-74.99)\end{array}$ & $\begin{array}{c}55.81 \\
(51.30-60.24)\end{array}$ & $\begin{array}{c}52.79 \\
(48.09-57.43)\end{array}$ & $\begin{array}{c}52.92 \\
(45.69-60.03)\end{array}$ & $\begin{array}{c}56.24 \\
(47.06-65.00)\end{array}$ & $\begin{array}{c}54.39 \\
(51.21-57.53)\end{array}$ & 0.8079 \\
\hline \multicolumn{8}{|l|}{ Schooling (years) } \\
\hline$<5$ & $\begin{array}{c}9.95 \\
(3.17-27.20)\end{array}$ & $\begin{array}{c}27.2 \\
(21.63-33.59)\end{array}$ & $\begin{array}{c}13.49 \\
(10.25-17.55)\end{array}$ & $\begin{array}{c}16.88 \\
(9.67-27.82)\end{array}$ & $\begin{array}{c}15.43 \\
(10.24-22.59)\end{array}$ & $\begin{array}{c}17.71 \\
(15.00-20.80)\end{array}$ & 0.0354 \\
\hline $5-8$ & $\begin{array}{c}25.36 \\
(16.30-37.20)\end{array}$ & $\begin{array}{c}24.58 \\
(20.57-29.08)\end{array}$ & $\begin{array}{c}27.97 \\
(23.38-33.07)\end{array}$ & $\begin{array}{c}29.81 \\
(23.02-37.62)\end{array}$ & $\begin{array}{c}24.96 \\
(20.39-30.15)\end{array}$ & $\begin{array}{c}26.87 \\
(24.27-29.64)\end{array}$ & \\
\hline 9 & $\begin{array}{c}64.69 \\
(55.69-72.76)\end{array}$ & $\begin{array}{c}48.23 \\
(39.07-57.50)\end{array}$ & $\begin{array}{c}58.54 \\
(51.34-65.39)\end{array}$ & $\begin{array}{c}53.31 \\
(40.23-65.95)\end{array}$ & $\begin{array}{c}59.61 \\
(49.35-69.10)\end{array}$ & $\begin{array}{c}55.41 \\
(50.96-59.78)\end{array}$ & \\
\hline $\begin{array}{l}\text { Partnered (versus } \\
\text { single) }\end{array}$ & $\begin{array}{c}45.39 \\
(28.53-63.38)\end{array}$ & $\begin{array}{c}62.58 \\
(57.07-67.78)\end{array}$ & $\begin{array}{c}59.22 \\
(52.83-65.30)\end{array}$ & $\begin{array}{c}54.19 \\
(45.01-63.09)\end{array}$ & $\begin{array}{c}70.62 \\
(58.27-80.53)\end{array}$ & $\begin{array}{c}59.6 \\
(55.19-63.86)\end{array}$ & 0.0815 \\
\hline \multicolumn{8}{|l|}{ Chronic conditions } \\
\hline No & $\begin{array}{c}42.33 \\
(33.09-52.13)\end{array}$ & $\begin{array}{c}55.16 \\
48.65-61.50)\end{array}$ & $\begin{array}{c}50.04 \\
(44.43-55.66)\end{array}$ & $\begin{array}{c}56.21 \\
(50.37-61.88)\end{array}$ & $\begin{array}{c}50.76 \\
(43.13-58.35)\end{array}$ & $\begin{array}{c}51.99 \\
(48.28-55.69)\end{array}$ & 0.1105 \\
\hline 1 & $\begin{array}{c}26.63 \\
(15.72-41.39)\end{array}$ & $\begin{array}{c}25.69 \\
(22.29-29.40)\end{array}$ & $\begin{array}{c}29.34 \\
(26.34-32.52)\end{array}$ & $\begin{array}{c}28.27 \\
(24.19-32.74)\end{array}$ & $\begin{array}{c}29.13 \\
(25.07-33.56)\end{array}$ & $\begin{array}{c}27.99 \\
(25.98-30.09)\end{array}$ & \\
\hline 2 & $\begin{array}{c}27.67 \\
(13.43-48.52)\end{array}$ & $\begin{array}{c}11.87 \\
(8.69-16.01)\end{array}$ & $\begin{array}{c}13.26 \\
(10.82-16.14)\end{array}$ & $\begin{array}{c}9.97 \\
(7.48-13.17)\end{array}$ & $\begin{array}{c}13.57 \\
(8.82-20.31)\end{array}$ & $\begin{array}{c}13.3 \\
(10.70-16.42)\end{array}$ & \\
\hline 3 & $\begin{array}{c}3.38 \\
(1.47-7.60)\end{array}$ & $\begin{array}{c}7.29 \\
(4.95-10.61)\end{array}$ & $\begin{array}{c}7.36 \\
(4.54-11.72)\end{array}$ & $\begin{array}{c}5.55 \\
(2.99-10.10)\end{array}$ & $\begin{array}{c}6.54 \\
(3.48-11.96)\end{array}$ & $\begin{array}{c}6.72 \\
(5.08-8.84)\end{array}$ & \\
\hline Poor self-rated health & $\begin{array}{c}7.39 \\
(3.38-15.40)\end{array}$ & $\begin{array}{c}16 \\
(11.13-22.46)\end{array}$ & $\begin{array}{c}10.04 \\
(7.87-12.72)\end{array}$ & $\begin{array}{c}13.41 \\
(7.90-21.86)\end{array}$ & $\begin{array}{c}11.36 \\
(7.86-16.14)\end{array}$ & $\begin{array}{c}12.16 \\
(10.10-14.57)\end{array}$ & 0.1472 \\
\hline $\begin{array}{l}\text { Previous doctor visit } \\
\text { (pre-COVID) }\end{array}$ & $\begin{array}{c}90.73 \\
(77.39-96.55)\end{array}$ & $\begin{array}{c}80.79 \\
(77.35-83.82)\end{array}$ & $\begin{array}{c}82.56 \\
(75.18-88.09)\end{array}$ & $\begin{array}{c}70.26 \\
(58.40-79.91)\end{array}$ & $\begin{array}{c}72.56 \\
(65.32-78.78)\end{array}$ & $\begin{array}{c}79.62 \\
(75.69,83.05)\end{array}$ & 0.0220 \\
\hline UBS & $\begin{array}{c}43.51 \\
(18.97-71.71)\end{array}$ & $\begin{array}{c}33.09 \\
(25.04-42.27)\end{array}$ & $\begin{array}{c}46.06 \\
(39.39-52.87)\end{array}$ & $\begin{array}{c}43.64 \\
(28.39-60.19)\end{array}$ & $\begin{array}{c}29.59 \\
(23.10-37.02)\end{array}$ & $\begin{array}{c}40.34 \\
(34.90-46.02)\end{array}$ & 0.1656 \\
\hline FHS & $\begin{array}{c}30.87 \\
(22.49-40.74)\end{array}$ & $\begin{array}{c}56.07 \\
(45.55-66.07)\end{array}$ & $\begin{array}{c}37.45 \\
(29.52-46.11)\end{array}$ & $\begin{array}{c}41.89 \\
(23.92-62.31)\end{array}$ & $\begin{array}{c}51.57 \\
(45.18-57.91)\end{array}$ & $\begin{array}{c}44.2 \\
(37.86,50.74)\end{array}$ & \\
\hline Private health plan & $\begin{array}{c}25.61 \\
(8.55,55.90)\end{array}$ & $\begin{array}{c}10.84 \\
(5.72-19.59)\end{array}$ & $\begin{array}{c}16.49 \\
(11.67-22.78)\end{array}$ & $\begin{array}{c}14.47 \\
(6.98-27.59)\end{array}$ & $\begin{array}{c}18.84 \\
(13.47-25.71)\end{array}$ & $\begin{array}{c}15.46 \\
(11.72-20.12)\end{array}$ & \\
\hline
\end{tabular}

95\%Cl: 95\% confidence interval; FHS: Family Health Strategy; UBS: public health centers.

Source: the ELSI-COVID-19 initiative (May/June, 2020).

* Numbers are weighted and survey-adjusted proportions/means with their $95 \% \mathrm{Cl}$ in brackets;

** $\mathrm{p}$-values from design-corrected F-test for differences in each category across geographic regions;

$\star \star \star$ COVID-19 related symptoms include fever, persistent dry cough, or difficulty breathing in the past 30 days. 
Table 2

Adjusted prevalence rates (PR) and 95\% confidence intervals (95\% CI) for factors associated with reporting COVID-19 related symptoms, seeking health care among those with at least one symptom, and previously scheduled care being canceled.

\begin{tabular}{|c|c|c|c|}
\hline & $\begin{array}{l}\text { Any related } \\
\text { symptom reported } \\
{[n=5,919]} \\
\text { PR }(95 \% \mathrm{Cl})\end{array}$ & $\begin{array}{c}\text { Sought care } \\
\text { for symptoms } \\
\text { [n = 568] * } \\
\text { PR }(95 \% \mathrm{Cl})\end{array}$ & $\begin{array}{l}\text { Scheduled care } \\
\text { was canceled } \\
\text { [n=5,891] } \\
\text { PR }(95 \% \mathrm{Cl})\end{array}$ \\
\hline \multicolumn{4}{|l|}{ Aged (years) } \\
\hline 60-69 (versus 49-59) & $0.81(0.63-1.05)$ & $0.78(0.46-1.31)$ & $0.81(0.58-1.12)$ \\
\hline $70-79$ & $0.64(0.43-0.98) * *$ & $0.90(0.57-1.42)$ & $0.77(0.52-1.13)$ \\
\hline 80 & $1.03(0.70-1.52)$ & $0.37(0.10-1.38)$ & $0.80(0.52-1.25)$ \\
\hline Female (versus male) & $1.04(0.76-1.44)$ & $1.16(0.70-1.92)$ & $1.47(1.08,1.99)$ ** \\
\hline \multicolumn{4}{|l|}{ Schooling (years) } \\
\hline $5-8$ (versus < 5) & $1.00(0.76-1.32)$ & $0.72(0.31-1.66)$ & $1.29(0.99-1.69)$ \\
\hline 9 & $1.20(0.89-1.63)$ & $1.10(0.70-1.74)$ & $1.77(1.32-2.38) * \star \star *$ \\
\hline Partnered (versus single) & $0.97(0.73-1.27)$ & - & $0.98(0.74-1.30)$ \\
\hline \multicolumn{4}{|l|}{ Chronic condition } \\
\hline 1 (versus none) & $0.91(0.64-1.28)$ & $1.05(0.52-2.12)$ & $1.31(0.95-1.80)$ \\
\hline 2 & $1.85(1.10-3.13)$ ** & $1.69(0.88-3.24)$ & $1.50(1.04-2.17)$ ** \\
\hline 3 & $3.16(2.17-4.59) * \star \star$ & $1.11(0.52-2.40)$ & $1.93(1.24,3.00) \#$ \\
\hline \multicolumn{4}{|l|}{ Poor self-rated health (versus excellent/ } \\
\hline good) & $1.19(0.83-1.69)$ & $1.14(0.68-1.91)$ & $1.08(0.85-1.37)$ \\
\hline FHS (versus UBS) & $1.36(0.94-1.98)$ & $1.04(0.65-1.68)$ & $0.80(0.61-1.06)$ \\
\hline Private health plan (versus UBS) & $1.02(0.56-1.84)$ & $1.42(0.81-2.48)$ & $0.74(0.46-1.20)$ \\
\hline Previous doctor visit (pre-COVID-19) & $1.27(0.83-1.93)$ & $0.92(0.49-1.73)$ & $2.36(1.40-3.98) \#$ \\
\hline \multicolumn{4}{|l|}{ Regions } \\
\hline Northeast (versus North) & $0.24(0.17-0.33) * \star *$ & $0.89(0.50-1.58)$ & $1.39(0.65-2.97)$ \\
\hline Southeast & $0.17(0.12-0.24) * \star *$ & $0.53(0.30-0.95) * *$ & $2.03(1.04-3.99) * \star$ \\
\hline South & $0.21(0.12-0.37) * \star \star$ & $0.29(0.13,0.62) \#$ & $1.19(0.57-2.48)$ \\
\hline Central & $0.12(0.07-0.19) * \star \star$ & $0.42(0.12-1.39)$ & $0.69(0.35-1.35)$ \\
\hline
\end{tabular}

FHS: Family Health Strategy; UBS: public health centers.

Note: adjusted PR and their $95 \% \mathrm{Cl}$ are estimated from survey-adjusted Poisson regression.

Source: the ELSI-COVID-19 initiative (May/June, 2020).

* Partnered not included in model due to lack of statistical significance and no contribution to model fit.

** $\mathrm{p}<0.05$

$* * * p<0.001$

$\# \mathrm{p}<0.01$.

\section{Discussion}

Our study presents a descriptive snapshot of some of the effects of the COVID-19 pandemic during the last week of May and the first week of June in a nationally-representative sample of Brazilian adults aged 50 years and over. It shows that in the 30 days prior to the interview about $10.4 \%$ of older adults reported any of the following three symptoms: fever, dry cough or difficulty breathing. The highest prevalence of self-reported symptoms was in the North region (50\%), where initial COVID-19 rates were higher (Coronavírus Brasil. Painel coronavírus. https://covid.saude.gov.br/, accessed on 21/Jun/2020). Moreover, sicker individuals were more likely to report symptoms.

Only 33.6\% of those with COVID-19 related symptoms in the past 30 days sought medical care for those symptoms. This fact may be related to a lack of knowledge about whether to seek testing based on symptoms, a lack of a clear communications strategy to inform citizens about what to do if they had symptoms, or the fact that some components of the health system stopped functioning, as 
Figure 1

Predicted probability of seeking care for COVID-19 related symptoms, by region and age group.

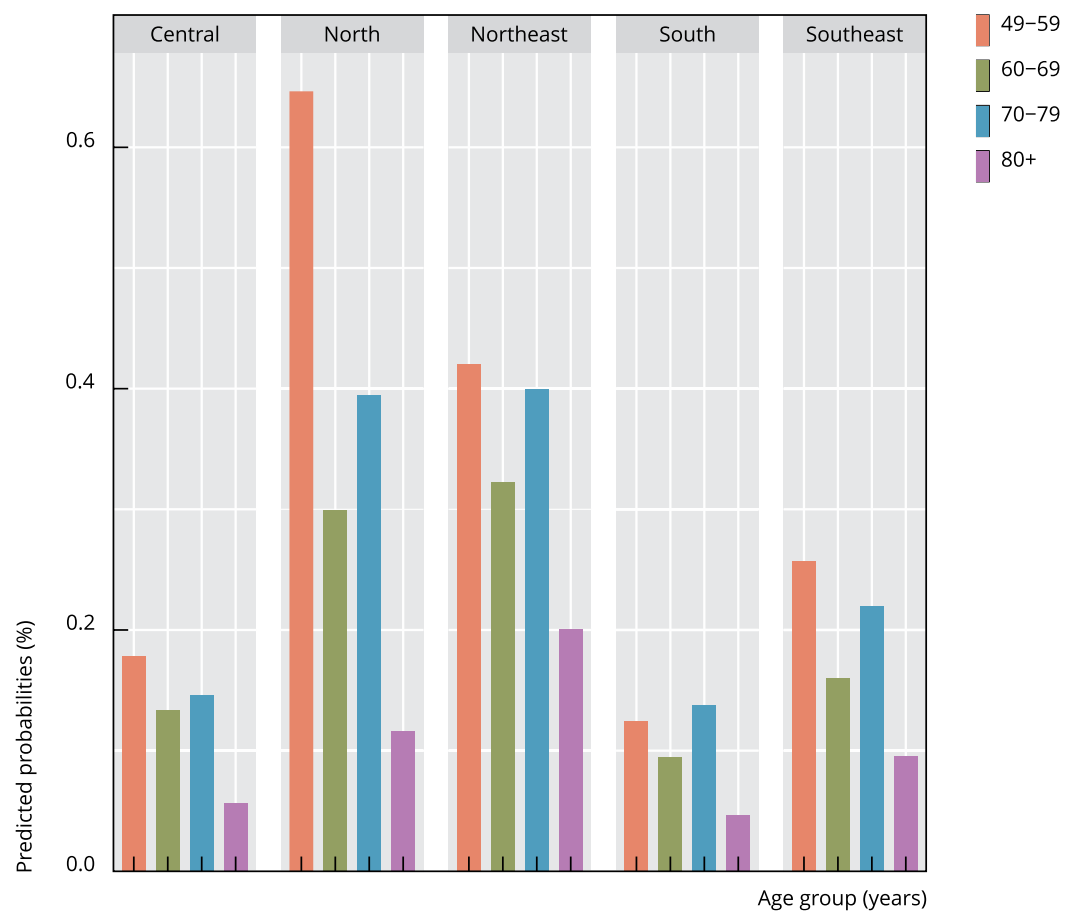

Note: predicted probabilities from model 2, Table 2.

Source: The ELSI-COVID-19 initiative (May/June, 2020).

evidenced by a temporary measure suspending performance goals for service providers in the Brazilian Unified National Health System (SUS), issued in April 2020 14. Moreover, individuals who did not feel they had serious symptoms or whose symptoms improved in a relatively short period of time may have chosen not to seek care. Sensitivity analyses (data not presented) suggest that barriers to health care access (lack of usual source of care, not being able to get a doctor's appointment within 24 hours, not being able to speak to the doctor by phone, and perception that one's usual doctor did not explain things clearly) were not associated ( $p>0.05)$ with care seeking among those with symptoms. This fact suggests that these barriers to access are not related to a lack of care-seeking among participants with at least one symptom.

The low level of care-seeking ones in this study is corroborated by previous. For example, patterns of medical care avoidance have been noted even for critical conditions such as heart attacks, as shown by a $48 \%$ decrease in patient hospitalization for acute myocardial infarction in one large private health care system in Northern California, United States, between January 1st and April 14th, 202015. Similarly, it is possible that fear of infection, particularly for high-risk patients, could be contributing to higher rates of medical care avoidance while also increasing risk of health complications due to non-COVID-19 related factors.

The increased mobilization of Brazilian hospitals, meant that $17.2 \%$ of people with scheduled surgery or other medical care had such care canceled. People with higher levels of education, women, and participants from the South Region were also more likely to have had to cancel care, potentially because they are more aware of the disease and are carrying out more strict social isolation measures. It is concerning that this rate was highest among the sickest older adults ( $3+$ chronic conditions). 


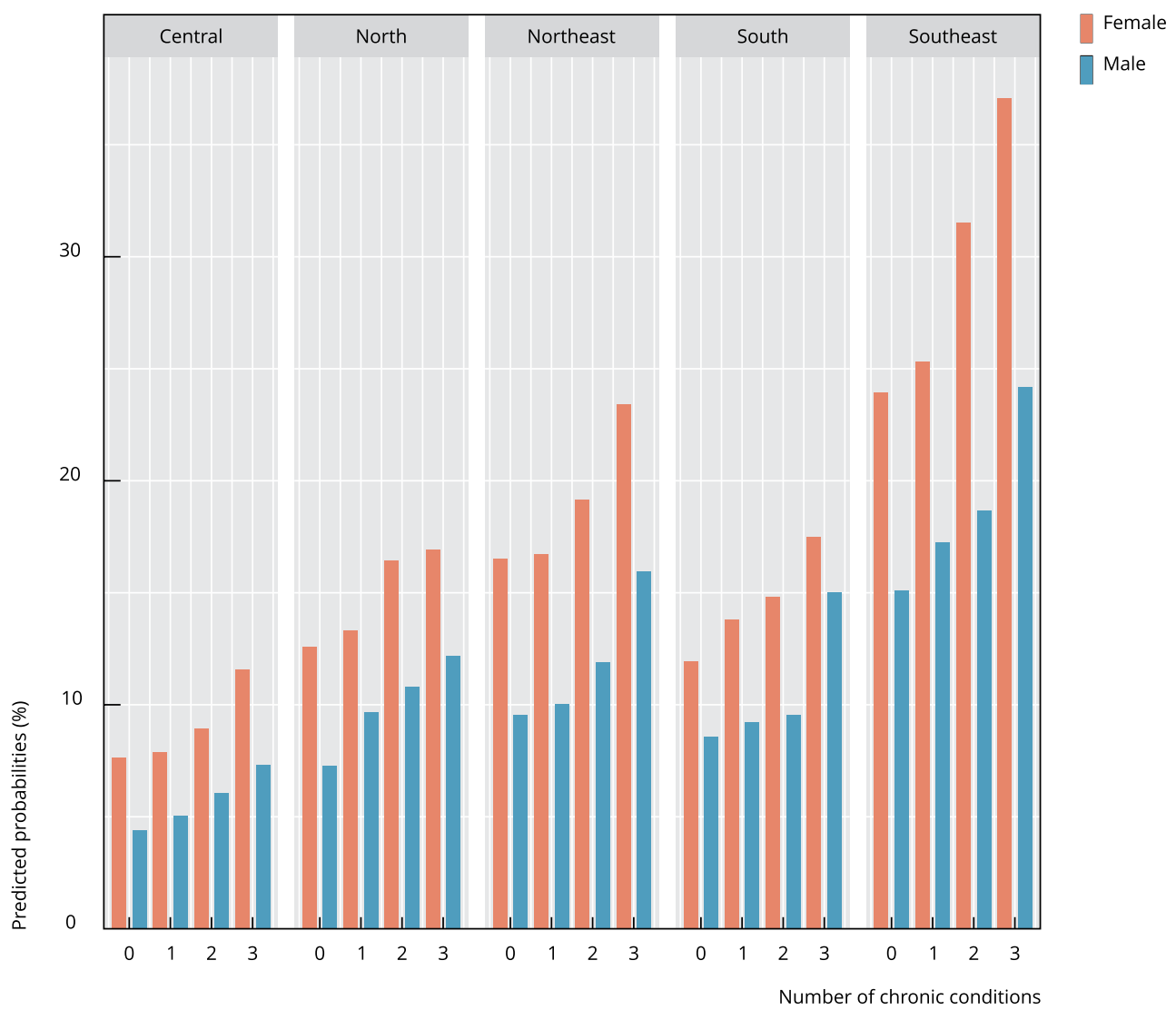

Note: predicted probabilities from model 3, Table 2. Source: the ELSI-COVID-19 initiative (May/June, 2020).

While current results showed no significant difference in the rate of reporting symptoms by sex in Brazil, females were more likely to have important medical care canceled. Studies in high-income countries suggest that women are more likely than men to believe COVID-19 poses serious health risks and to comply with preventive measures (e.g. social distancing and handwashing) 16 . These dynamics might have also occurred in this study, although it is not possible to rule out that the current findings were simply due to higher rates of health care use by women overall.

As the pandemic continues, it may have additional gender effects. Higher mortality has been observed in men, due in part because of higher rates of some underlying factors (i.e. higher rates of smoking, and other chronic conditions) 17 . However, gender differences in having medical care canceled may have an additional effect on morbidity and even mortality attributed to other diseases that require timely treatment. For example, survival rates for breast and ovarian cancers are critically affected by the onset of treatment and it should be closely monitored 18 . More widespread availability of COVID-19 cases and mortality data disaggregated by sex is necessary to further assess the association between sex and COVID-19 infection and mortality as well as the consequences of canceling ongoing care. 
The COVID-19 pandemic has set in motion profound societal changes at an unprecedented pace, including in health care scenario. In Brazil, regulations on teleconferencing between physicians and patients had long been debated 19 but were quickly adopted during the pandemic 20. Telemedicine can help the expansion of health care access to hard-hit, underserved areas such as the North and Northeastern regions of Brazil, in addition to minimizing infection exposure 19. On the other hand, those who could benefit the most from telemedicine services, namely people aged 60 and older, might lack the infrastructure and digital literacy to use them effectively 21 . Furthermore, a physical encounter is indispensable for healthcare delivery, especially for individuals with multiple chronic conditions. Therefore, it is important that policy-makers and health care administrators continue to expand measures to ensure that when visits to health care facilities are required, they occur in a safe and timely manner.

This study has several limitations. Firstly, all results are self-reported, thus the risk of recall bias should not be discounted. Regarding symptoms, most of these are fairly typical of many respiratory illnesses, so they may not have been identified by participants as indicative of COVID-19. For health care seeking, we do not know if participants were able to use an alternative source of care, such as phone hotlines or whether telemedicine was substituted for an in-person doctor visit. It is not possible to assess whether the cancellation of previously scheduled surgery or medical care was permanent, or whether it was simply delayed. It was also not possible to infer whether the cancellation was initiated by the patient or the health care provider. Strategies to mitigate the first and the second would probably differ, although it is likely that a combination of both would be necessary. Also, non-trivial level of refusal in participating might have partially biased results if the participants who did not respond to the telephone survey were sicker or otherwise different from other participants.

\section{Conclusions}

While this preliminary study has a number of limitations based on the self-reported and crosssectional nature of data and the rapidly changing scenario of an ongoing pandemic, the patterns identified in this study indicate a need to redouble efforts to control the pandemic in Brazil. Urgentlyneeded measures include evidence-based approaches to promote voluntary quarantine-especially for older and more vulnerable individuals, continued closing of large public institutions and restrictions on public gatherings, widespread, and consistent use of face masks and physical distancing measures, and greatly intensified testing and contact tracing 6,22,23,24. Regarding health care, the promotion of telemedicine use and bringing testing closer to where people live will be particularly important for older Brazilians who may be unable to seek care on their own or for those who are reluctant to seek care due to fear or lack of clear guidelines. Systems are also necessary to prioritize individuals who have urgent non-COVID-19-related health needs. Current forecasting models predict that without immediate attention to infection control measures - consistently applied across all geographic areas of the country - the rates of infection and mortality will continue to rise and the health system may collapse 25,26 . The resulting catastrophe will affect everyone, but Brazil's older citizens, especially those with chronic conditions and those living in the poorest regions of the country, are particularly at risk for some of the most severe consequences. 


\section{Contributors}

J. Macinko carried out the study design, data analysis, contributed to the manuscript writing and supervised the work. N. O. Woolley .arried out the literature review and writing. B. V. Seixas participated in the literature review, writing and data visualization. F. B. Andrade participated in the data collection and study design. M. F. Lima-Costa directed the survey, data collection and study design; reviewed and approved the final manuscript. All authors reviewed and approved the final manuscript.

\section{Additional informations}

ORCID: James Macinko (0000-0001-8055-5441); Natalia Oliveira Woolley (0000-0002-3780-7006); Brayan V. Seixas (0000-0002-3863-0572); Fabiola Bof de Andrade (0000-0002-3467-3989); Maria Fernanda Lima-Costa (0000-0002-3474-2980).

\section{Acknowledgments}

The baseline and second wave of the ELSI-Brasil aging cohort study was funded by the Brazilian Ministry of Health: Department of Science and Technology of the Department of Science and Technology and Strategic Inputs - DECIT/SCTI) (Opinion n. 404965/2012-1 e 28/2017) and Health Coordination for the Elderly of the Health Care Secretariat - COSAPI/DAPES/SAS (TED: 20836, 22566, 23700 and 77/2019). The ELSI-COVID-19 initiative is funded by DECIT/SCTI and by the Brazilian National Research Council (CNPq: Opinion n. 403473/2020-9). Maria Fernanda Lima-Costa is supported by a $\mathrm{CNPq} 1 \mathrm{~A}$ research productivity award.

\section{References}

1. World Health Organization. Coronavirus disease (COVID-19): situation report - 149. https://reliefweb.int/report/world/corona virus-disease-covid-19-situation-report149-17-june-2020 (accessed on 21/Jun/2020).

2. Onder G, Rezza G, Brusaferro S. Case-fatality rate and characteristics of patients dying in relation to COVID-19 in Italy. JAMA 2020; 323:1775-6.

3. Szwarcwald CL, Souza Júnior PRB, Marques AP, Almeida WS, Montilla DER. Inequalities in healthy life expectancy by Brazilian geographic regions: findings from the National Health Survey, 2013. Int J Equity Health 2016; 15:141.

4. Brazil Coronavirus map and case count. The New York Times 2020. https://www.nytimes. com/interactive/2020/world/americas/bra zil-coronavirus-cases.html (accessed on 22/ Jun/2020).

5. Wilder-Smith A, Freedman DO. Isolation, quarantine, social distancing and community containment: pivotal role for old-style public health measures in the novel coronavirus (2019-nCoV) outbreak. J Travel Med 2020; 27:taaa020.

6. Kucharski AJ, Klepac P, Conlan AJK, Kissler SM, Tang ML, Fry H, et al. Effectiveness of isolation, testing, contact tracing, and physical distancing on reducing transmission of SARSCoV-2 in different settings: a mathematical modelling study. Lancet Infect Dis 2020; 20:1151-60.

7. Lockdown já ocorre em cidades do Rio de Janeiro, Pará, Tocantins, Amapá, Roraima e Paraná. Folha S.Paulo 2020; 17 may. https:// www1.folha.uol.com.br/cotidiano/2020/05/ lockdown-ja-ocorre-em-cidades-do-rio-dejaneiro-para-tocantins-amapa-roraima-e-pa rana.shtml.

8. Ronan G. Dados indicam que Minas não é referência em isolamento social; veja por que. Estado de Minas 2020; 26 may. https://www. em.com.br/app/noticia/gerais/2020/05/26/ interna_gerais, $1150923 /$ dados-indicam-queminas-nao-e-referencia-em-isolamento-so cial-veja-po.shtml.

9. Paiva D. Quarentena em bairros da periferia de São Paulo tem partidas de futebol, bares abertos e ônibus lotados. G1 2020; 08 apr. https://g1.globo.com/sp/sao-paulo/noti$\mathrm{cia} / 2020 / 04 / 08 /$ quarentena-em-bairros-daperiferia-de-sao-paulo-tem-partidas-de-fute bol-bares-abertos-e-onibus-lotados.ghtml.

10. Doze capitais têm mais de $80 \%$ de leitos públicos de UTI ocupados. Folha de S.Paulo 2020; 20 may. https://www1.folha.uol.com.br/co tidiano/2020/05/doze-capitais-tem-mais-de80-de-leitos-publicos-de-uti-ocupados.shtml.

11. Lima-Costa MF, Andrade FB, Souza PRB, Neri AL, Duarte YAO, Castro-Costa E, et al. The Brazilian Longitudinal Study of Aging (ELSI-Brazil): objectives and design. Am J Epidemiol 2018; 187:1345-53. 
12. Lima-Costa MF, Macinko J, Andrade FB, Souza Jr. PRB, Vasconcellos MTL, Oliveira CM. ELSI-COVID-19: methodology of the telephone survey on coronavirus in the Brazilian Longitudinal Study of Aging. Cad Saúde Pública 2020; 36 Suppl 3:e00183120.

13. Heeringa SG, West BT, Berglund PA. Applied survey data analysis. Boca Raton: Chapman and Hall/CRC; 2010.

14. Brasil. Lei no 13.992, de 22 de abril de 2020. Suspende por 120 (cento e vinte) dias, a contar de 1o de março do corrente ano, a obrigatoriedade da manutenção das metas quantitativas e qualitativas contratualizadas pelos prestadores de serviço de saúde no âmbito do Sistema Único de Saúde (SUS). Diário Oficial da União 2020; 23 apr.

15. Solomon MD, McNulty EJ, Rana JS, Leong TK, Lee C, Sung S-H, et al. The Covid-19 pandemic and the incidence of acute myocardial infarction. N Engl J Med 2020; 383:691-3.

16. Galasso V, Pons V, Profeta P, Becher M, Brouard S, Foucault M. Gender differences in COVID-19 related attitudes and behavior: evidence from a panel survey in eight OECD Countries. http://www.nber.org/papers/ w27359 (accessed on 22/Jun/2020).

17. Wenham C, Smith J, Morgan R; Gender and COVID-19 Working Group. COVID-19: the gendered impacts of the outbreak. Lancet 2020; 395:846-8.

18. Ho PJ, Cook AR, Binte Mohamed Ri NK, Liu J, Li J, Hartman M. Impact of delayed treatment in women diagnosed with breast cancer: a population-based study. Cancer Med 2020; 9:2435-44.

19. Maldonado JMSV, Marques AB, Cruz A. Telemedicine: challenges to dissemination in Brazil. Cad Saúde Pública 2016; 32 Suppl 2:e00155615.
20. Brasil. Lei no 13.989 , de 15 de abril de 2020 . Dispõe sobre o uso da telemedicina durante a crise causada pelo coronavírus (SARS-CoV-2). Diário Oficila da União 2020; 16 abr.

21. Nishijima M, Ivanauskas TM, Sarti FM. Evolution and determinants of digital divide in Brazil (2005-2013). Telecommunications Policy $2017 ; 41: 12-24$.

22. Gostic K, Gomez AC, Mummah RO, Kucharski AJ, Lloyd-Smith JO. Estimated effectiveness of symptom and risk screening to prevent the spread of COVID-19. Elife 2020; 24:9.

23. MacIntyre CR. Case isolation, contact tracing, and physical distancing are pillars of COVID-19 pandemic control, not optional choices. Lancet Infect Dis 2020; 20:1105-6.

24. Breeher L, Boon A, Hainy C, Murad MH, Wittich C, Swift M. A framework for sustainable contact tracing and exposure investigation for large health systems. Mayo Clin Proc 2020; 95:1432-44.

25. Silva TC, Anghinoni L, Zhao L. Quantitative analysis of the effectiveness of public health measures on COVID-19 Transmission. medRxiv 2020; 18 may. https://www.medrxiv. org/content/10.1101/2020.05.15.20102988v1.

26. Canabarro A, Tenorio E, Martins R, Martins L, Brito S, Chaves R. Data-driven study of the COVID-19 Pandemic via age-structured modelling and prediction of the health system failure in Brazil amid diverse intervention strategies. medRxiv 2020; 15 apr. http://medrxiv. org/lookup/doi/10.1101/2020.04.03.2005249. 


\section{Resumo}

O continente americano apresenta o maior número de pessoas infectadas e de mortes associadas à síndrome respiratória grave do coronavírus 2 (SARS-CoV-2) no mundo. O Brasil ocupa a 2a posição em números de casos de infectados e de óbitos, antecedido somente pelos Estados Unidos. Adultos mais velhos e aqueles com doenças crônicas preexistentes são mais vulneráveis às consequências da infecção. A epidemia do SARS-CoV-2 tem enormes consequências para os serviços de saúde. Portanto, é urgente avaliar o efeito da pandemia na população idosa brasileira. Nosso objetivo foi examinar a prevalência de sintomas da COVID-19, a busca por atenção em saúde em função destes sintomas, e o cancelamento de cirurgias, ou outros procedimentos previamente agendados, por causa da pandemia, em uma amostra representativa de brasileiros adultos com 50 anos ou mais, participantes do Estudo Longitudinal da Saúde dos Idosos Brasileiros (ELSI-Brasil), que responderam à entrevista telefônica sobre a COVID-19 entre o final de maio e o início de junho de 2020. Entre os participantes, 10,4\% informaram ter tido febre, tosse seca ou dificuldades para respirar nos 30 dias anteriores à entrevista telefônica, com maior prevalência na Região Norte (50\%). Entre aqueles com qualquer um desses sintomas, somente 33,6\% haviam procurado por assistência em saúde; esta proporção foi ainda menor nas regiões Sul e Sudeste. Cerca de 1 entre 6 participantes havia cancelado cirurgias ou outros procedimentos anteriormente agendados; esta proporção foi maior entre as mulheres, entre aqueles com escolaridade mais alta e entre aqueles com múltiplas doenças crônicas. Este trabalho está entre os primeiros a examinar as consequências da epidemia da COVID-19 no uso de serviços de saúde entre brasileiros mais velhos. Os resultados apontam para a necessidade de adaptação da oferta da atenção à saúde para garantir a continuidade dos cuidados necessários durante a epidemia (como telemedicina, por exemplo), bem como a necessidade urgente de ampla divulgação para orientar a população sobre a prevenção da doença e como obter atenção em saúde em caso de necessidade

Envelhecimento; COVID-19; Acesso aos Cuidados de Saúde

\section{Resumen}

El continente de las Américas tiene el mayor número de personas infectadas y muertes asociadas con el síndrome respiratorio agudo severo coronavirus 2 (SARS-CoV-2) en el mundo. El Brasil ocupa la $2^{a}$ posición en número de casos infectados y defunciones, solo precedido por los Estados Unidos. Los adultos mayores y aquellos con enfermedades crónicas preexistentes son más vulnerables a las consecuencias del virus. La epidemia de SARS-CoV-2 tiene graves consecuencias para los servicios de salud. Por lo tanto, se necesita con urgencia una evaluación del efecto de la pandemia en la población brasileña de mayor edad. El estudio examina la prevalencia de COVID-19, sus sintomas asociados, la búsqueda de cuidados, y la cancelación de cirugías -u otros cuidados médicos agendados- en una muestra nacionalmente representativa de brasileños, con una edad de 50 años o más, proveniente del Estudio Brasileño Longitudinal del Envejecimiento (ELSI-Brasil, por sus siglas en portugués), además de una encuesta telefónica de seguimiento (la iniciativa ELSICOVID-19) entre finales de mayo y principios de junio de 2020. Aproximadamente un 10,4\% de los adultos mayores no informaron de tener fiebre, tos seca o dificultad para respirar en los 30 días previos a la entrevista, con la prevalencia más alta en la región Norte (50\%). Entre los individuos con sintomas, solamente un 33,6\% solicitaron asistencia. Aproximadamente 1 de cada 6 participantes tuvo que cancelar una cirugía agendada $u$ otra intervención médica. Las personas que viven en las regiones Sur o Sudeste tuvieron significativamente menos probabilidad de buscar asistencia médica por sintomas relacionados con la COVID-19. Mujeres, así como los individuos con más educación, $y$ pacientes con múltiples enfermedades crónicas tenían más probabilidades de que se les cancelara la asistencia médica, debido a la pandemia. Este trabajo está entre los primeros en investigar el impacto de la COVID-19 en el uso de los servicios de salud en Brasil entre adultos mayores. Los resultados resaltan la necesidad de adaptar la provisión de asistencia médica, a través de medios como la telemedicina, para superar la denegación de la asistencia necesaria, así como la imperiosa necesidad de un enfoque de salud pública más fuerte para proteger a las personas vulnerables.

Envejecimiento; COVID-19; Acceso a la Atención de Salud

Submitted on 30/Jun/2020

Final version resubmitted on 03/Aug/2020

Approved on 07/Aug/2020 